\title{
DETERMINAN KINERJA GURU \\ (STUDI PADA SEKOLAH MENENGAH ATAS DAN \\ SEKOLAH MENENGAH KEJURUAN SE KECAMATAN JATISARI \\ KABUPATEN KARAWANG)
}

Eka Yuda Prasetya

adyuta2207@gmail.com

\begin{abstract}
ABSTRAK
Masalah yang diangkat dalam penelitian ini adalah: untuk mengetahui, menjelaskan dan menganalisis Kepemimpinan Kepala Sekolah, Motivasi Kerja Dan Budaya Organisasi Terhadap Kinerja Guru serta pengaruh parsial dan simultan Kepemimpinan, Motivasi Kerja Dan Budaya Organisasi Terhadap Kinerja Guru Pada Sekolah Menengah Atas dan Sekolah Menengah Kejuruan Se Kabupaten Karawang.

Jumlah sampel yang diambil sebanyak 170 Guru dengan teknik sampling jenuh. tesis ini diharapkan dapat memberikan sumbangan bagi pengembangan bidang manajemen khususnya manajemen sumber daya manusia. Metode penelitian yang digunakan penulis dalam penulisan ini menggunakan metode deskriptif dan verifikatif, dari hasil analisis data penelitian diperoleh beberapa kesimpulan sebagai berikut: (1) Kepemimpinan Kepala Sekoalah $\left(\mathrm{X}_{1}\right)$ di SMA dan SMK se Kabupaten Karawang Sudah Baik, Motivasi Kerja $\left(\mathrm{X}_{2}\right)$ di SMA dan SMK Se Kabupaten Karawang Sudah Baik, Budaya Organisasi $\left(X_{3}\right)$ di SMA dan SMK Se Kabupaten Karawang sudah baik, Kinerja Guru (Y) di SMA dan SMK Se Kabupaten Karawang Sudah baik. (2) Koefisien korelasi antara variabel bebas yaitu Kepemimpinan Kepala Sekolah $\left(\mathrm{X}_{1}\right)$ dan Motivasi Kerja $\left(\mathrm{X}_{2}\right)$, kemudian Motivasi Kerja $\left(\mathrm{X}_{2}\right)$ dan Budaya Organisasi $\left(\mathrm{X}_{3}\right)$ serta Kepemimpinan Kepala Sekolah $\left(\mathrm{X}_{1}\right)$ dan Budaya Organisasi $\left(\mathrm{X}_{3}\right)$ ketiga variable bebas tersebut memiliki tingkat hubungan yang kuat dan searah karena nilai positif.(3)Kepemimpinan Kepala Sekolah secara parsial mempunyai pengaruh yang positif dan signifikan terhadap Kinerja. (4)Motivasi Kerja secara parsial mempunyai pengaruh yang positif dan signifikan terhadap Kinerja (5) Budaya Organisasi secara parsial mempunyai pengaruh yang positif dan signifikan terhadap Kinerja. Budaya organisasi merupakan variable yang paling berpengaruh terhadap kinerja guru (6) Kepemimpinan Kepala sekolah $\left(\mathrm{X}_{1}\right)$, Motivasi $\left(\mathrm{X}_{2}\right)$ dan Budaya Organisasi $\left(\mathrm{X}_{3}\right)$ secara simultan berpengaruh positif dan signifikan terhadap Kinerja Guru(Y).
\end{abstract}

Kata Kunci: Kepemimpinan Kepala Sekolah, Motivasi Kerja, Budaya Organisasi, Kinerja Guru

67. 


\section{A. PENDAHULUAN}

Sumber Daya Manusia (SDM) merupakan aset penting untuk menunjang keberhasilan suatu organisasi. SDM adalah pelaksana seluruh kebijakan organisasi sehingga perlu dibekali dengan pengetahuan yang memadai. Pentingnya sumber daya manusia ini perlu disadari oleh semua tingkatan manajemen. meskipun dengan semakin pesatnya perkembangan teknologi saat ini, tetapi faktor manusia tetap memegang peranan penting bagi keberhasilan suatu organisasi.

Kabupaten karawang merupakan wilayah yang terletak di Jawa Barat yang terdiri dari 30 kecamatan salah satunya adalah kecamatan Jatisari. Kecamatan Jatisari memiliki beberapa sekolah tingkat atas baik Sekolah Menengah Atas ataupun Sekolah Menengah Kejuruan. Dengan adanya kedua jenis sekolah tersebut diharapkan dapat meningkatkan kualitas pendidikan masyarakat serta mempermudah masyarakat untuk mendapatkan pelayanan pendidikan yang memadai diwilayah jatisari pada khususnya dan masyarakat karawang pada umumnya. Untuk menilai kualitas pendidikan yang dihasilkan dapat dilihat dari bagaimana kinerja guru pada kedua sekolah tersebut. Salah satu indikator penilaian kinerja guru yaitu melalui hasil Ujian Nasional peserta didik yang ada dibawah binaannya. Berikut adalah rata-rata hasil Ujian Nasional SMA dan SMK di kecamatan Jatisari karawang.



Gambar

Hasil Ujian Nasional SMA se Kecamatan Jatisari

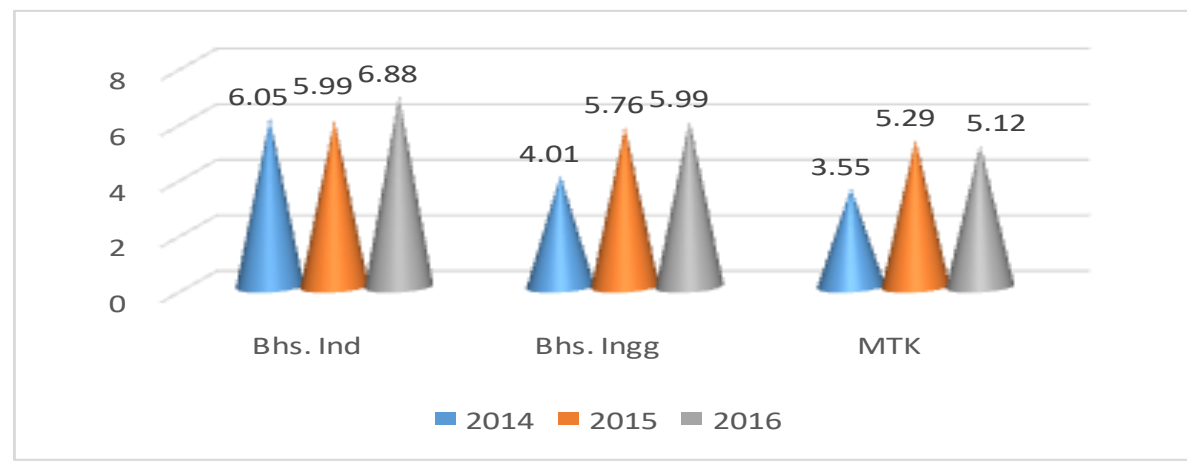

Sumber: Hasil Ujian SMK se Kecamatan Jatisari

Gambar

Hasil Ujian Nasional SMK se Kecamatan Jatisari

68. 
Berdasarkan data diatas dapat disimpulkan bahwa nilai rerata ujian SMA dan SMK cenderung berfluktuasi yaitu pada mata pelajaran bahasa inggris dan matematika sedangkan untuk mata pelajaran bahasa Indonesia cenderung meningkat, tetapi apabila diambil rata-rata dari semua mata pelajaran nilai siswa masih dibawah angka 6 dan tidak ada yang mencapai nilai 7. Hal ini menunjukan bahwa terdapat masalah dengan kinerja guru.

Menurut Sopiah (2008:123) ada dua fungsi penting yang harus ada pada seorang pemimpin yaitu Fungsi Tugas dan fungsi pemeliharaan yang terdiri dari Mendorong Semangat,Monitoring, Menetapkan standar, Mengurangi ketegangan, Menciptakan Keharmonisan. Berdasarkan hasil penelitian pendahuluan mengenai pendidikan dan pelatihan terhadap 30 orang responden dengan penyebaran kuisioner didapatkan hasil sebagai berikut:

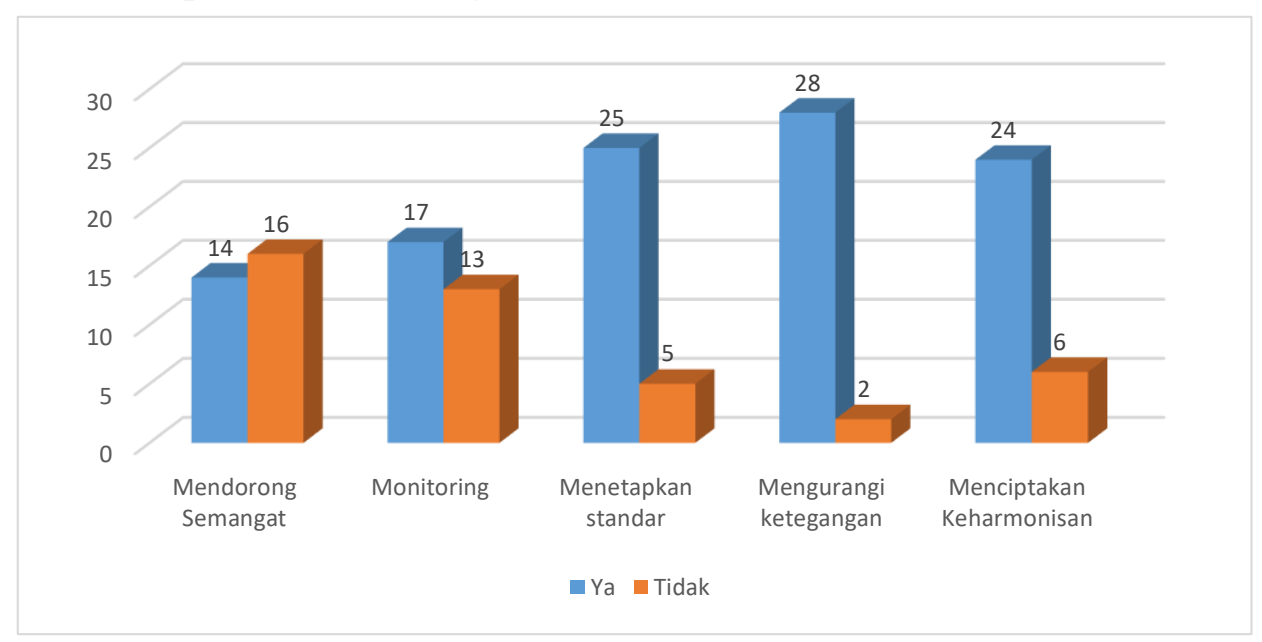

Sumber: pra survey 2017

\section{Gambar}

\section{Hasil Prasurvey Kepemimpinan Kepala Sekolah}

Berdasarkan data diatas dapat ditarik kesimpulan bahwa kepala sekolah jarang mendorong semangat dan melakukan monitoring kepada para guru dalam menjalankan tugasnya sebagai pendidik.

Berikut adalah data hasil penelitian pendahuluan mengenai motivasi kerja terhadap 30 orang responden di SMA dan SMK Kecamatan Jatisari Karawang.

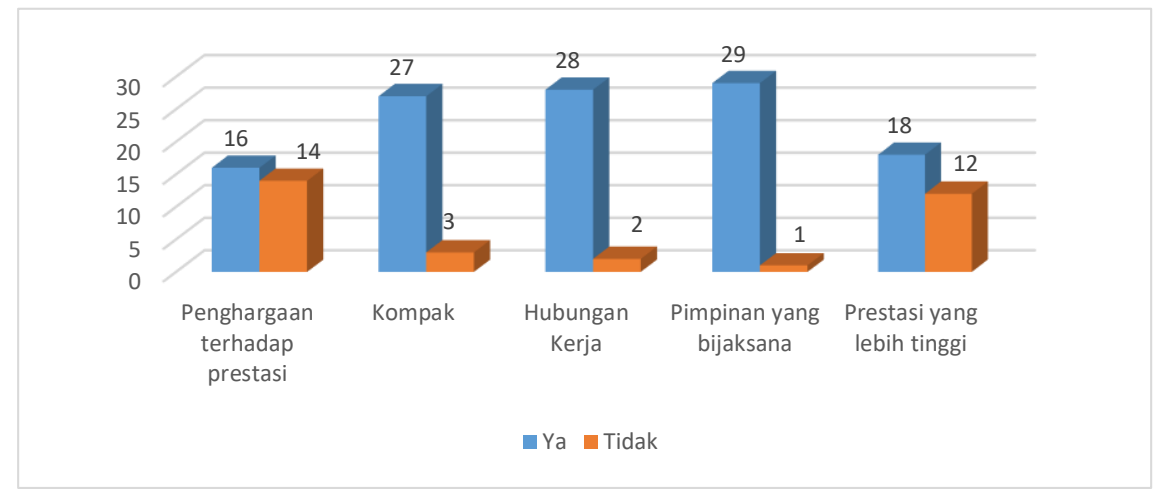

Sumber: pra survey 2017

Gambar

Hasil Prasurvey Motivasi Kerja 
Berdasarkan data diatas dapat ditarik kesimpulan bahwa beberapa guru merasa jarang diberikan penghargaan terhadap prestasi yang telah mereka capai serta jarang diarahkan untuk dapat mencapai pestasi yang lebih tinggi.

Berikut data hasil penelitian pendahuluan terhadap 30 orang responden mengenai budaya organisasi.

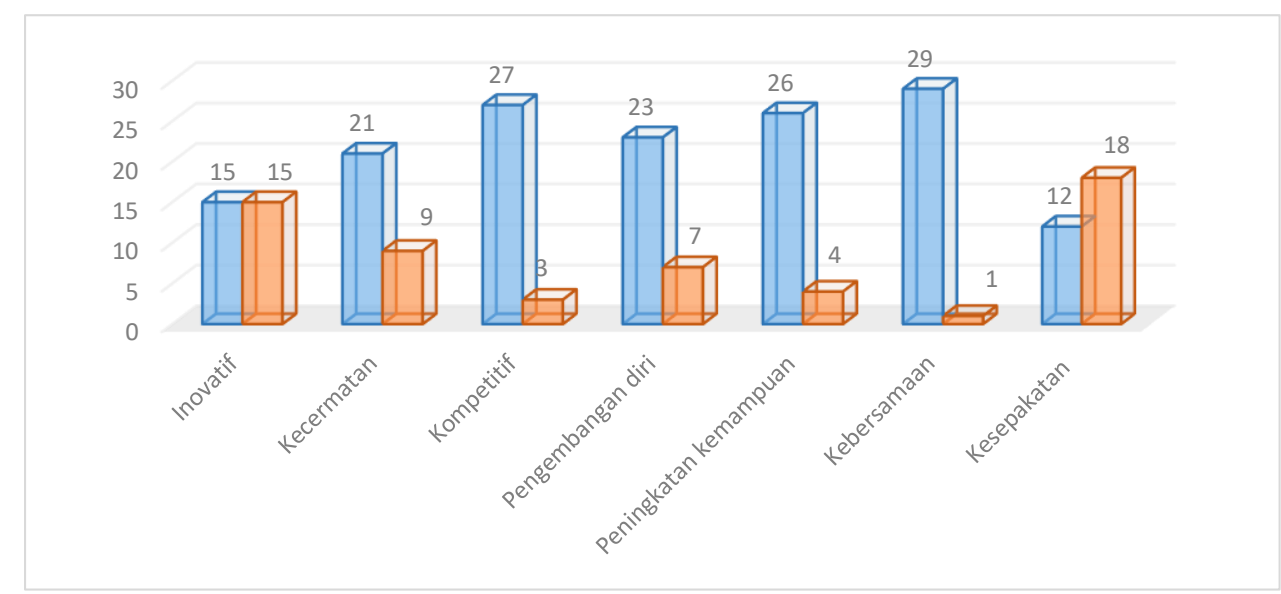

Sumber: Prasurvey 2017

Gambar

Hasil Prasurvey Budaya Organisasi

Berdasarkan data diatas dapat diatrik kesimpulan bahwa sekolah kurang menekankan kepada guru lebih inovatif untuk kemajuan sekolah serta dalam pengambilan kebijakan kurang memperhatikan hal yang telah disepakati bersama. Hal ini menunjukan masih rendahnya budaya organisasi yang ada disekolah.

\section{B. TINJAUAN PUSTAKA}

\subsection{Kinerja Pegawai}

Setiap manusia mempunyai potensi untuk bertindak dalam berbagai bentuk aktivitas. Kemampuan bertindak itu diperoleh manusia baik secara alami (ada sejak lahir) atau dipelajari. Walaupun manusia mempunyai potensi untuk berperilaku tertentu, tetapi perilaku itu hanya diaktualisasi pada saat-saat tertentu. Potensi untuk berperilaku tertentu itu disebut ability (kemampuan), sedangkan ekspresi dari potensi ini dikenal sebagai performance (kinerja). Secara operasional kinerja dapat didefinisikan sebagai tindakan atau pelaksanaan tugas yang telah diselesaikan oleh seseorang dalam kurun waktu tertentu dan dapat diukur.

Menurut Mahsum dalam buku Masana Sembiring (2012:81) "kinerja adalah gambaran mengenai tingkat pencapaian pelaksanaan suatu kegiatan/program/kebijakan dalam mewujudkan sasaran, tujuan, misi, dan visi organisasi".

Kemudian Indra Bastian yang dikutip oleh Irham Fahmi (2011:2), Kinerja adalah gambaran mengenai tingkat pencapaian pelaksanaan suatu kegiatan atau program dan kebijakan dalam mewujudkan sasaran, tujuan, 
misi dan visi organisasi yang tertuang dalam perumusan skema strategis (strategic planning) suatu organisasi.

Kinerja (performance) menurut Bangun (2012:231) adalah hasil pekerjaan yang dicapai seseorang berdasarkan persyaratan-persyaratan pekerjaan (job requirement).

Selanjutnya definisi kinerja menurutmangkunegara (2008:67) "kinerja adalah hasil kerja secara kualitas dan kuantitas yang dicapai seseorang pegawai dalam melaksanakan tugasnya sesuai dengan tanggung jawab yang diberikan kepadanya".

Sedangkan definisi kinerja menurut Tjutju Yunarsih dan Suwanto (2008:161) menyatakan bahwa "Kinerja merupakan prestasi yang nyata ditampilkan seseorang setelah yang bersangkutan menjalankan tugas dan perannya dalam organisasi".

Sedangkan menurut Supardi, (2014:4) "Kinerja merupakan suatu kegiatan yang dilakukan untuk melaksanakan, menyelesaikan tugas dan tanggung jawab sesuai dengan harapan dan tujuan yang telah ditetapkan".

Sedangkan menurut Hamzah B Uno (2014:86) "Kinerja guru adalah hasil kerja guru yang terefleksi dalam cara merencanakan, melaksanakan dan menilai proses belajar mengajar yang intensitasnya dilandasi oleh etos kerja, serta disiplin profesional dalam proses pembelajaran".

Sedangkan menurut Peraturan Pemerintah No. 46 Tahun 2011 meyatakan bahwa "Kinerja guru selain ditunjukkan oleh prestasi kerja, juga ditunjukkan oleh perilaku dalam bekerja".

\subsection{Kepemimpinan Kepala Sekolah}

Pemimpin merupakan unsur vital dalam sebuah organisasi, dan dalam setiap kegiatannya pemimpin di tuntut untuk memiliki kemampuan yang baik, hal tersebut terjadi karena para pemimpin membawahi sekelompok orang dalam melaksanakan tugas sehingga dapat mencapai tujuan tugas tersebut. Dengan kepemimpinan yang baik, maka peran bawahan akan berjalan dengan baik pula.

Menurut Siswanto (2010:154), pengertian kepemimpinan adalah:

Sifat dan perilaku untuk mempengaruhi para bawahannya agar mereka mampu bekerja sama sehingga membentuk jalinan kerja yang harmonis dengan pertimbangan aspek efisien dan efektif untuk mencapai tingkat produktivitas kerja sesuai dengan yang telah ditetapkan.

Adapun pendapat lain yang menjelaskan mengenai kepemimpinan Menurut Ulber Silalahi (2012:310) yang mengemukakan bahwa kepemimpinan adalah "Tindakan mempengaruhi perilaku seseorang atau sekelompok orang kearah pencapaian tujuan-tujuan”.

Selanjutnya Menurut Husaini Usman (2011:282) "Kepemimpinan merupakan ilmu dan seni memengaruhi orang atau kelompok untuk bertindak seperti yang diharapkan untuk mencapai tujuan secara efektif dan efisien".

Dengan demikian Kepemimpinan adalah Proses seseorang dalam mempengaruhi orang lain atau kelompok agar dapat mengikuti apa yang di inginkannya dengan menggunakan aturan-aturan dan norma-norma yang 
berlaku, sehingga tercipta tujuan yang di inginkannya secara efektif dan efisien.

\subsection{Motivasi}

Setiap organisasi tentu ingin mencapai tujuan. Untuk mencapai tujuan tersebut, peranan manusia yang terlibat di dalamnya sangat penting. Untuk mengerakan manusia agar sesuai dengan yang dikehendaki organisasi, maka haruslah dipahami motivasi manusia yang bekerja di dalam organisasi tersebut, karena motivasi inilah yang menentukan perilaku orang-orang untuk bekerja, atau dengan kata lain perilaku merupakan cerminan yang paling sederhana dari motivasi. Motivasi adalah suatu faktor yang mendorong seseorang untuk melakukan suatu aktivitas tertentu, oleh karena itu motivasi sering kali diartikan pula sebagai faktor pendorong perilaku seseorang. Setiap aktivitas yang dilakukan oleh seseorang pasti memiliki suatu faktor yang mendorong aktivitas tersebut. Oleh karena itu, faktor pendorong dari seseorang untuk melakukan suatu aktivitas tertentu pada umumnya adalah kebutuhan serta keinginan orang tersebut.

Adapun sumber-sumber dari para ahli, yang mengartikan Motivasi sebagai berikut:

Menurut Malayu S.P Hasibuan (2011:144) "Motivasi adalah hal yang menyebabkan, menyalurkan dan mendukung perilaku manusia, supaya mau bekerja giat dan antusias dalam mencapai hasil yang optimal”.

Menurut Stephen P. Robbins dan Mary Counter dalam buku Suwanto dan Donni Juni Priansa (2011:171) menyatakan motivasi adalah kesediaan untuk melaksanakan upaya tinggi untuk mencapai tujuan-tujuan keorganisasian yang dikondisikan oleh kemampuan upaya untuk memenuhi kebutuhan individu tertentu.

Selanjutnya definisi menurut Hasibuan dalam buku Edy Sutrisno (2009:111): "Motivasi adalah pemberian daya penggerak yang menciptakan kegairahan kerja seseorang agar mereka mau bekerja sama, bekerja efektif dan terintegrasi dengan segala upayanya untuk mencapai kepuasan".

Sedangkan definisi menurut Robbins dalam buku Edy Sutrisno (2009:111) mengemukakan motivasi adalah suatu kerelaan berusaha seoptimal mungkin dalam pencapaian tujuan organisasi yang dipengaruhi oleh kemampuan usaha memuaskan beberapa kebutuhan individu.

Selanjutnya menurut Sondang Siagian (2008:287) yang menyatakan bahwa "Motivasi adalah dorongan untuk berbuat semaksimal mungkin dalam melaksanakan tugasnya demi mencapai keberhasilan dan tujuan organisasi, sehingga kepentingan pribadi karyawan pun akan terpelihara pula".

Selain itu pendapat ahli lain yang mengungkapkan mengenai motivasi, menurut A.A. Anwar Prabu Mangkunegara (2008:61) mengemukakan bahwa: "Motivasi merupakan kondisi atau energi yang menggerakkan diri karyawan yang terarah atau tertuju untuk mencapai tujuan organisasi perusahaan." 


\subsection{Budaya Organisasi}

Menurut Ahmad Fuad Fanani dalam Indrawijaya (2010:196) "budaya adalah system nilai yaitu nilai-nilai yang sudah menjadi suatu system dan tidak berdiri lepas satu-satu, dan menjadi keyakinan bersama untuk berimajinasi dan berekpresi".

Sedangkan menurut Koentjaraningrat dalam Indrawijaya (2010:195) menyatakan bahwa "budaya adalah sebagai keseluruhan system gagasan tindakan dan hasil karya manusia dalam rangka kehidupan masyarakat yang dijadikan milik diri manusia dengan cara belajar".

Menurut Peter F. Druicker dalam pabundu Tika (2010:4) bahwa:

Budaya organisasi adalah pokok penyelesaian masalah-masalah eksternal dan Internal yang pelaksanaannya dilakukan secara konsisten oleh suatu kelompok dan kemudian mewariskan kepada anggota-anggota baru sebagai cara yang tepat untuk memahami, memikirkan dan merasakan terhadap masalah-masalah terkait.

Menurut Stephen P. Robbins dalam Sopiah (2008:128) "Budaya Organisasi adalah sistem makna bersama yang dianut oleh anggotaanggotanya dan yang membedakan antara satu organisasi dengan lainnya". Sedangkan menurut Indrawijaya (2010:198) menyatakan bahwa:

Budaya Organisasi adalah keseluruhan nilai, norma-norma, kepercayaankepercayaan dan opini-opini yang dianut dan dijunjung tinggi bersama oleh para anggota organisasi, sehingga kebudayaan tersebut memberi arah dan corak kepada (way of thinking, way of live) anggota-anggota organisasi tersebut, kebiasan (custom) dan tradisi (tradition).

Pabundu Tika (2010:5) Unsur-unsur dalam budaya organisasi meliputi asumsi dasar, keyakinan yang dianut pengembangan budaya organisasi, pedoman mengatasi masalah, pewarisan, penyesuaian.

1. Asumsi dasar

Dalam budaya organisasi terdapat asumsi dasar yang berfungsi sebagai pedoman bagi anggota maupun kelompok dalam organisasi untuk berperilaku

2. Keyakinan yang dianut

Dalam budaya organisasi terdapat keyakinanyang dianut dan dilaksanakan oleh para anggota organisasi.Keyakinan ini mengandung nilai-nilai yang dapat terbentuk slogan atau moto, asumsi dasar, tujuan umum organisasi/perubahan, filosofi usaha, atau prinsip-prinsip menjelaskan usaha.

3. Pengembangan budaya organisasi

Budaya organisasi perlu diciptakan dan dikembangkan oleh pemimpin organisasi/perusahaan atau kelompok tertentu dalam organisasi atau perusahaan tersebut.

4. Pedoman mengatasi masalah

Dalam organisasi/perubahan, terdapat dua masalah pokok yang sering muncul, yakni masalah adaptasi eksternal dan masalah integrasi internal. Kedua masalah tersebut dapat diatasi dengan asumsi dasar dan keyakinan yang dianut bersama anggota organisasi.

5. Pewarisan 
Asumsi dasar dan keyakinan yang dianut oleh anggota organisasi perlu diwariskan kepada anggota-anggota baru dalam organisasi sebagai pedoman untuk bertindak dan berperilaku dalam organisasi/perusahaan tersebut.

6. Penyesuaian

Perlu penyesuaian anggota kelompok terhadap peraturan atau norma yang berlaku dalam kelompok atau organisasi tersebut, serta adaptasi organisasi/perusahaan terhadap perubahan lingkungan.

\section{METODE PENELITIAN DAN ANALISIS DATA}

Metode penelitian pada dasarnya merupakan cara ilmiah untuk mendapatkan data dengan tujuan dan kegunaan tertentu. Cara ilmiah kegiatan penelitian itu didasarkan pada ciri-ciri keilmuan, yaitu rasional, empiris, dan sistematis (Sugiyono 2012:2). Dalam penelitian ini menggunakan metode penelitian deskriptif dan verifikatif.

Menurut Sugiyono (2012:35), penelitian deskriptif adalah penelitian yang dilakukan untuk mengetahui nilai variabel mandiri, baik satu variabel atau lebih (independent) tanpa membuat perbandingan atau menghubungkan dengan variabel yang lain.

Penelitian verifikatif menurut Sugiyono (2012:3) bahwa metode penelitian kuantitatif yang digunakan untuk penelitian populasi atau sampel tertentu, dan analisis data bersifat statistik dengan tujuan untuk menguji hipotesis yang telah ditetapkan.

Tujuan dari penelitian deskriptif ada lah untuk memperoleh gambaran secara sistematis mengenai Kepemimpinan Kepala Sekolah, motivasi kerja, Budaya Organisasi sebagai variabel bebas dan kinerja Guru sebagai variabel terikat, sedangkan secara verifikatif bertujuan untuk menguji hipotesis dengan perhitungan statistik.

\section{HASIL PENELITIAN}

\section{Profil Responden}

Responden dalam penelitian ini adalah SMA dan SMK se kecamatan Jatisari Karawang yang berjumlah 170 orang, dengan karakteristik sebagai berikut:

Tabel

Jumlah Responden Berdasarkan Jenis Kelamin

\begin{tabular}{|c|c|c|c|}
\hline No & Usia & Jumlah (orang) & Persentase \\
\hline 1 & Laki-laki & 70 & 41.2 \\
\hline 2 & Perempuan & 100 & 58.8 \\
\hline \multicolumn{2}{|c|}{ Total } & 170 & 100 \\
\hline
\end{tabular}

Sumber: Hasil pengolahan data, 2017

Tabel

Jumlah Responden Berdasarkan Usia

\begin{tabular}{|c|c|c|c|}
\hline No & Jenis Kelamin & Jumlah (orang) & Persentase \\
\hline 1 & Dibawah 26 Tahun & 41 & 3.5 \\
\hline 2 & $26-30$ Tahun & 59 & 31.8 \\
\hline 3 & $31-35$ Tahun & 33 & 41.2 \\
\hline 4 & Diatas 36 Tahun & 21 & 23.5 \\
\hline
\end{tabular}




\begin{tabular}{|c|c|c|}
\hline Total & 170 & 100 \\
\hline
\end{tabular}

Sumber: Hasil pengolahan data, 2017

Tabel

Jumlah Responden Berdasarkan Lama Kerja

\begin{tabular}{|c|c|c|l|}
\hline No & Jenis Kelamin & $\begin{array}{c}\text { Jumlah } \\
\text { (orang) }\end{array}$ & Persentase \\
\hline 1 & $\begin{array}{c}\text { Dibawah } 1 \\
\text { Tahun }\end{array}$ & 13 & 1.2 \\
\hline 2 & $1-2$ Tahun & 49 & 7.6 \\
\hline 3 & $2-3$ Tahun & 82 & 28.8 \\
\hline 4 & $3-4$ tahun & 24 & 48.2 \\
\hline 5 & Diatas 4 Tahun & 13 & 14.1 \\
\hline \multicolumn{2}{|c|}{ Total } & 170 & 100 \\
\hline
\end{tabular}

Sumber : Hasil pengolahan data, 2017

Tabel

Jumlah Responden Berdasarkan Pendidikan

\begin{tabular}{|c|c|c|c|}
\hline No & Jenis Kelamin & $\begin{array}{c}\text { Jumlah } \\
\text { (orang) }\end{array}$ & Persentase \\
\hline 1 & SD & 0 & 0 \\
\hline 2 & SMP & 0 & 0 \\
\hline 3 & SMA & 0 & 0 \\
\hline 4 & D1 & 2 & 1.2 \\
\hline 5 & D2 & 3 & 1.8 \\
\hline 6 & D3 & 67 & 39.4 \\
\hline 7 & S1 & 70 & 41.2 \\
\hline 8 & S2 & 28 & 16.5 \\
\hline & Total & 170 & 100 \\
\hline
\end{tabular}

Sumber: Hasil pengolahan data, 2017

\section{Pengujian Keabsahan Data}

Uji Validitas

Tabel

Hasil Uji Validitas Variabel Kepemimpinan

\begin{tabular}{|l|c|c|c|c|}
\hline \multicolumn{1}{|c|}{ Dimensi } & Pernyataan & r Hitung & r Kritis & Kriteria \\
\hline Perencana yang tangguh & 1 & 0.554 & & Valid \\
\hline Strategi yang tepat & 2 & 0.661 & & Valid \\
\hline Organisator yang cekatan & 3 & 0.385 & & Valid \\
\hline Motivator yang efektif & 4 & 0.427 & & Valid \\
\hline Objektif dan rasional & 5 & 0.558 & & Valid \\
\hline Mendengarkan pendapat & 6 & 0.391 & \multirow{4}{*}{0.3} & Valid \\
\hline Partisipasi & 7 & 0.503 & Valid \\
\hline Pemberdayaan & 8 & 0.531 & & Valid \\
\hline Mendorong semangat & 9 & 0.416 & & Valid \\
\hline Menetapkan standar & 10 & 0.326 & & Valid \\
\hline Monitoring & 11 & 0.584 & & Valid \\
\hline Mengekspresikan & 12 & 0.491 & & Valid \\
\hline
\end{tabular}

75. 


\begin{tabular}{|l|c|c|c|c|}
\hline perasaan & & & \multirow{5}{*}{} & \\
\hline Mengurangi ketegangan & 13 & 0.444 & & Valid \\
\hline Keharmonisan & 14 & 0.305 & & Valid \\
\hline
\end{tabular}

Sumber: Hasil Pengolahan Data, 2017

Tabel

Hasil Uji Validitas Variabel Motivasi

\begin{tabular}{|l|c|c|c|c|}
\hline \multicolumn{1}{|c|}{ Dimensi } & Pernyataan & r Hitung & r Kritis & Kriteria \\
\hline Penghargaan terhadap prestasi & 1 & 0.369 & & Valid \\
\hline Semangat kerja & 2 & 0.545 & & Valid \\
\hline Prestasi yang lebih tinggi & 3 & 0.446 & & Valid \\
\hline Tanggung jawab & 4 & 0.474 & \multirow{5}{*}{0.3} & Valid \\
\hline Melakukan pekerjaan lebih baik & 5 & 0.510 & & Valid \\
\hline Hubungan Kerja & 6 & 0.481 & & Valid \\
\hline Kekompakan & 7 & 0.509 & Valid \\
\hline Kompensasi yang memadai & 8 & 0.592 & & Valid \\
\hline Pimpinan yang bijaksana & 9 & 0.401 & & Valid \\
\hline Kepercayaan & 10 & 0.517 & & Valid \\
\hline Peraturan yang fleksibel & 11 & 0.544 & & Valid \\
\hline Pengakuan & 12 & 0.496 & & Valid \\
\hline Kepuasan akan pekerjaan & 13 & 0.409 & & Valid \\
\hline Kontribusi & 14 & 0.456 & & Valid \\
\hline
\end{tabular}

Sumber: Hasil Pengolahan Data, 2017

Tabel

Hasil Uji Validitas Variabel Kompensasi

\begin{tabular}{|l|c|c|c|c|}
\hline \multicolumn{1}{|c|}{ Dimensi } & Pernyataan & $\begin{array}{c}\text { r } \\
\text { Hitung }\end{array}$ & \multirow{2}{*}{ r Kritis } & Kriteria \\
\hline Inovatif & 1 & 0.426 & & Valid \\
\hline Kecermatan & 2 & 0.348 & & Valid \\
\hline Kompetitif & 3 & 0.390 & & Valid \\
\hline Pengembangan diri & 4 & 0.639 & & Valid \\
\hline \begin{tabular}{l|l|l|} 
Peningkatan \\
kemampuan
\end{tabular} & 5 & 0.486 & & Valid \\
\hline Kebersamaan & 6 & 0.503 & \multirow{4}{*}{0.3} & Valid \\
\hline Kesepakatan bersama & 7 & 0.658 & & Valid \\
\hline Terbuka & 8 & 0.364 & & Valid \\
\hline Proaktif & 9 & 0.377 & & Valid \\
\hline Fokus pada hasil & 10 & 0.470 & & Valid \\
\hline Kesetiaan & 11 & 0.489 & & Valid \\
\hline Perilaku & 12 & 0.485 & & Valid \\
\hline Kepastian & 13 & 0.640 & & Valid \\
\hline Kemantapan & 14 & 0.605 & & Valid \\
\hline
\end{tabular}

Sumber: Hasil Pengolahan Data, 2017 
Tabel

Hasil Uji Validitas Variabel Kinerja

\begin{tabular}{|l|c|l|c|c|}
\hline \multicolumn{1}{|c|}{ Dimensi } & Pernyataan & $\begin{array}{c}\text { r } \\
\text { Hitung }\end{array}$ & r Kritis & Kriteria \\
\hline Dorongan untuk bekerja & 1 & 0.491 & & Valid \\
\hline Tanggungjawab & 2 & 0.585 & & Valid \\
\hline Rencana pembelajaran & 3 & 0.403 & & Valid \\
\hline Kurikulum pembelajaran & 4 & 0.543 & & Valid \\
\hline Program semester & 5 & 0.526 & & Valid \\
\hline Kegiatan pembelajaran & 6 & 0.487 & & Valid \\
\hline Evaluasi dari kepala & 7 & 0.599 & \multirow{2}{*}{0.3} & Valid \\
\hline $\begin{array}{l}\text { Perhatian } \\
\text { sekolah }\end{array}$ & 8 & 0.550 & & Valid \\
\hline $\begin{array}{l}\text { Pelaksanaan } \\
\text { pengayaan }\end{array}$ & 9 & 0.576 & & Valid \\
\hline Hubungan interpersonal & 10 & 0.593 & & Valid \\
\hline $\begin{array}{l}\text { Peluang untuk } \\
\text { berkembang }\end{array}$ & 11 & 0.314 & & Valid \\
\hline Karya inovatif & 12 & 0.514 & & Valid \\
\hline Publikasi ilmiah & 13 & 0.452 & & Valid \\
\hline Kelompok diskusi & 14 & 0.435 & & Valid \\
\hline
\end{tabular}

Sumber: Hasil Pengolahan Data, 2017

Uji Reliabilitas

Tabel

Hasil Uji Reliabilitas

\begin{tabular}{|c|l|c|c|c|}
\hline No & \multicolumn{1}{|c|}{ Variabel } & r Hitung & r Kritis & Keterangan \\
\hline 1 & $\begin{array}{l}\text { Kepemimpinan } \\
\text { Kepala Sekolah }\left(\mathrm{X}_{1}\right)\end{array}$ & 0.835 & & $\begin{array}{c}\text { Sangat } \\
\text { Reliabel }\end{array}$ \\
\cline { 2 - 3 } 2 & Motivasi $\left(\mathrm{X}_{2}\right)$ & 0.844 & \multirow{2}{*}{0.70} & $\begin{array}{c}\text { Sangat } \\
\text { Reliabel }\end{array}$ \\
\cline { 1 - 2 } 3 & $\begin{array}{l}\text { Budaya Organisasi } \\
\left(\mathrm{X}_{3}\right)\end{array}$ & 0.850 & & $\begin{array}{c}\text { Sangat } \\
\text { Reliabel }\end{array}$ \\
\cline { 1 - 2 } 3 & Kinerja Guru (Y) & 0.856 & & $\begin{array}{c}\text { Sangat } \\
\text { Reliabel }\end{array}$ \\
\hline
\end{tabular}

Sumber : Hasil pengolahan data, 2017

Uji Normalitas

Tabel

Hasil Uji Normalitas

\begin{tabular}{|l|c|c|c|}
\hline \multirow{2}{*}{ Variabel } & \multicolumn{2}{|c|}{ Kolmogrov - Smirnov } & \multirow{2}{*}{ Keterangan } \\
\cline { 2 - 2 } & $\begin{array}{c}\mathrm{r} \\
\text { Hitung }\end{array}$ & r Kritis & \\
\hline $\begin{array}{l}\text { Kepemimpinan Kepala Sekolah } \\
\left(\mathrm{X}_{1}\right)\end{array}$ & 0.050 & \multirow{2}{*}{0.05} & $\begin{array}{c}\text { Distribusi } \\
\text { Normal }\end{array}$ \\
\hline Motivasi $\left(\mathrm{X}_{2}\right)$ & 0.068 & $\begin{array}{c}\text { Distribusi } \\
\text { Normal }\end{array}$ \\
\hline
\end{tabular}




\begin{tabular}{|l|c|c|c|}
\hline Budaya Organisasi $\left(\mathrm{X}_{3}\right)$ & 0.066 & \multirow{5}{*}{} & $\begin{array}{c}\text { Distribusi } \\
\text { Normal }\end{array}$ \\
\cline { 1 - 2 } Kinerja Guru (Y) & 0.084 & & $\begin{array}{c}\text { Distribusi } \\
\text { Normal }\end{array}$ \\
\hline
\end{tabular}

Sumber: Hasil pengolahan data, 2017

\section{E. PEMBAHASAN HASIL TEMUAN PENELITIAN \\ Persamaan Jalur}

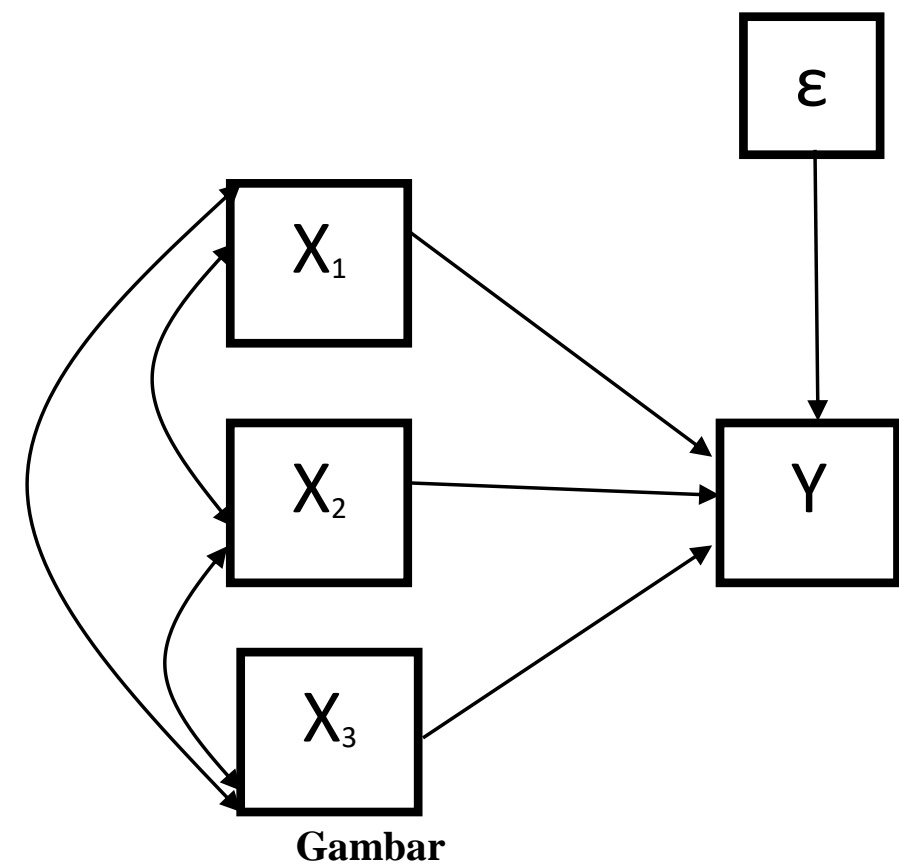

Koefisien JalurVariabel Displin Kerja $\left(\mathbf{X}_{1}\right)$ Motivasi $\left(\mathbf{X}_{2}\right)$ dan Budaya Organisasi ( $\left.\mathrm{X}_{3}\right)$ terhadap Kinerja Guru (Y)

Berdasarkan gambar diatas menunjukan bahwa besaran derajat positif asosiatif atau koefisien jalur variabel Budaya Organisasi $\left(\mathrm{X}_{3}\right)$ 0,427 lebih tinggi dari variabel Kepemimpinan Kepala Sekolah ( $\mathrm{X}_{1}$ ) 0.229 dan Motivasi 0,324, artinya Budaya Organisasi $\left(\mathrm{X}_{3}\right)$ lebih berpengaruh terhadap Kinerja Guru (Y) dibandingkan dengan Kepemimpinan Kepala Sekolah $\left(\mathrm{X}_{1}\right)$ dan Motivasi $\left(\mathrm{X}_{2}\right)$. Adapun persamaan jalurnya adalah sebagai berikut:

$$
Y=0,229 X_{1}+0,324 X_{2}+0,427 X_{3}+\varepsilon
$$

Keterangan

$$
\begin{aligned}
& \mathrm{X}_{1}=\text { Kepemimpinan Kepala Sekolah } \\
& \mathrm{X}_{2}=\text { Motivasi } \\
& \mathrm{X}_{3}=\text { Budaya Organisasi }
\end{aligned}
$$




$$
\begin{aligned}
& \mathrm{Y}=\text { KInerja Guru } \\
& \varepsilon \quad=\text { Variabel lain yang tidak diukur, tetapi mempengaruhi } \mathrm{Y}
\end{aligned}
$$

\section{Pengujian Hipotesis \\ Hipotesis Pengaruh secara Parsial Kepemimpinan $\left(\mathrm{X}_{1}\right)$ terhadap Kinerja Guru(Y)}

Pengaruh Kepemimpinan Kepala Sekolah secara parsial terhadap Kinerja Guru dapat diketahui melalui pengujian statistik dengan menggunakan hipotesis sebagai berikut :

$H_{0}: \rho x_{1} x_{2}=0$ Kepemimpinan Kepala Sekolah tidak berpengaruh terhadap Kinerja Guru

$H_{1}: \rho x_{1} x_{2} \neq 0$ Kepemimpinan Kepala Sekolah berpengaruh terhadap Kinerja

Guru

Kriteria Uji : Tolak $\mathrm{H}_{\mathrm{o}}$ jika Sig. $<\alpha$ atau $\mathrm{t}_{\text {hitung }}>\mathrm{t}_{\text {tabel }}$

Untuk pengaruh Kepemimpinan Kepala Sekolahsecara parsial terhadap Kinerja Guru dengan tingkat signifikan $(\alpha)=5 \%$, degree of freedom $(\mathrm{df})=$ $(n-2)=170-2=168$ diperoleh $t_{\text {tabel }}=1,654$. Berdasarkan tabel 4.70 di atas, menunjukan bahwa $t_{\text {hitung }}=4.431$ dan sig. 0,000. Pengaruh $\mathrm{X}_{1}$ secara Parsial terhadap Y diperlihatkan pada tabel 4.77 sebagai berikut :

\section{Tabel}

Pengaruh Parsial

Kepemimpinan Kepala Sekolah $\left(X_{1}\right)$ terhadap Kinerja Guru(Y)

\begin{tabular}{|c|c|c|c|c|c|}
\hline Structural & Sig. & $\boldsymbol{\alpha}$ & $\mathbf{t}_{\text {hitung }}$ & $\mathbf{t}_{\text {tabel }}$ & Kesimpulan \\
\hline pyx $_{1}$ & 0,000 & 0,05 & 4.431 & 1,654 & $\mathrm{H}_{\mathrm{o}}$ ditolak \\
\hline
\end{tabular}

Sumber : Hasil Pengolahan Data, 2017

Tabel diatas menunjukan bahwa nilai sig. $(0,000)>\alpha(0,05)$ dan $t_{\text {hitung }}$ $(4.431)>t_{\text {tabel }}(1,654)$ maka $H_{o}$ ditolak. Dengan demikian dapat disimpulkan bahwa Kepemimpinan Kepala Sekolahsecara parsial berpengaruh positif dan signifikan terhadap KInerja Guru.

Hipotesis Secara Parsial Motivasi Kerja $\left(\mathbf{X}_{2}\right)$ terhadap Kinerja Guru(Y) Pengaruh Motivasi secara parsial terhadap Kinerja Guru dapat diketahui melalui pengujian statistik dengan menggunakan hipotesis sebagai berikut :

$H_{0}$ : Motivasi tidak berpengaruh terhadap Kinerja Guru

$H_{1}$ : Motivasi berpengaruh terhadap Kinerja Guru

Kriteria Uji : Tolak $\mathrm{H}_{\mathrm{o}}$ jika Sig. $<\alpha$ atau thitung $>\mathrm{t}_{\text {tabel }}$

Untuk pengaruh Motivasisecara parsial terhadap Kinerja Gurudengan tingkat signifikan $(\alpha)=5 \%$, degree of freedom $(\mathrm{df})=(\mathrm{n}-2)=170-2=168$ diperoleh $\mathrm{t}_{\text {tabel }}=1,654$. Berdasarkan tabel 4.70 di atas, menunjukan bahwa $\mathrm{t}_{\text {hitung }}=5.034$ dan sig. 0,000. Pengaruh $\mathrm{X}_{2}$ secara parsial terhadap $\mathrm{Y}$ diperlihatkan pada tabel sebagai berikut:

Tabel

Pengaruh Parsial

Motivasi Kerja $\left(\mathbf{X}_{2}\right)$ terhadap Kinerja Guru (Y)

\begin{tabular}{|c|c|c|c|c|c|}
\hline Structural & Sig. & $\alpha$ & thitung & t tabel & Kesimpulan \\
\hline
\end{tabular}




\begin{tabular}{|c|c|c|c|c|c|}
\hline Pyx $_{2}$ & 0,000 & 0,05 & 5.034 & 1,654 & $\mathrm{H}_{\mathrm{o}}$ ditolak \\
\hline
\end{tabular}

Sumber : Hasil Pengolahan Data, 2017

Tabel diatas menunjukan bahwa nilai sig. $(0,000)<\alpha(0,05)$ dan $t_{\text {hitung }}$ $(5.034)>t_{\text {tabel }}(1,654)$ maka $\mathrm{H}_{\mathrm{o}}$ ditolak. Dengan demikian dapat disimpulkan bahwa Motivasisecara parsial berpengaruh positif dan signifikan terhadap KInerja Guru.

\section{Hipotesis Pengaruh Parsial Budaya Organisasi $\left(\mathrm{X}_{3}\right)$ terhadap Kinerja Guru(Y)}

Pengaruh Budaya Organisasi secara parsial terhadap Kinerja Gurudapat diketahui melalui pengujian statistik dengan menggunakan hipotesis sebagai berikut :

$H_{0}$ : Budaya Organisasi tidak berpengaruh terhadap Kinerja Guru

$H_{1}$ : Budaya Organisasi berpengaruh terhadap Kinerja Guru

Kriteria Uji : Tolak $\mathrm{H}_{\mathrm{o}}$ jika Sig. $<\alpha$ atau $\mathrm{t}_{\text {hitung }}>\mathrm{t}_{\text {tabel }}$

Untuk pengaruh Budaya Organisasi secara parsial terhadap Kinerja Gurudengan tingkat signifikan $(\alpha)=5 \%$, degree of freedom $(\mathrm{df})=(\mathrm{n}-2)=$ $170-2=168$ diperoleh $t_{\text {tabel }}=1,654$. Berdasarkan tabel 4.70 di atas, menunjukan bahwa $t_{\text {hitung }}=5.095$ dan sig. 0,000. Pengaruh $\mathrm{X}_{2}$ secara parsial terhadap Y diperlihatkan pada tabel sebagai berikut:

\section{Tabel}

\section{Pengaruh Parsial}

Budaya Organisasi $\left(\mathbf{X}_{3}\right)$ terhadap Kinerja Guru (Y)

\begin{tabular}{|c|c|c|c|c|c|}
\hline Structural & Sig. & $\boldsymbol{\alpha}$ & $\mathbf{t}_{\text {hitung }}$ & $\mathbf{t}_{\text {tabel }}$ & Kesimpulan \\
\hline $\mathrm{Pyx}_{3}$ & 0,000 & 0,05 & 7.320 & 1,654 & $\mathrm{H}_{\mathrm{o}}$ ditolak \\
\hline
\end{tabular}

Sumber : Hasil Pengolahan Data, 2017

Tabel diatas menunjukan bahwa nilai sig. $(0,000)<\alpha(0,00)$ dan $t_{\text {hitung }}$ $(7.320)>t_{\text {tabel }}(1,654)$ maka $\mathrm{H}_{\mathrm{o}}$ ditolak. Dengan demikian dapat disimpulkan bahwa Budaya Organisasi secara parsial berpengaruh positif dan signifikan terhadap KInerja Guru.

\section{Hipotesis Pengaruh Variabel Secara Simultan}

Pengaruh Kepemimpinan Kepala Sekolah $\left(\mathrm{X}_{1}\right)$, Motivasi $\left(\mathrm{X}_{2}\right)$ dan Budaya Organisasi $\left(\mathrm{X}_{3}\right)$ secara simultan (keseluruhan) terhadap Kinerja Guru(Y) dapat diketahui melalui pengujian statistik dengan menggunakan hipotesis sebagai berikut:

$H_{0}$ : Kepemimpinan Kepala Sekolah, Motivasi dan Budaya Organisasi secara simultan tidak berpengaruh terhadap Kinerja Guru

$H_{1}$ : Kepemimpinan Kepala Sekolah, Motivasi dan Budaya Organisasi secara simultan berpengaruh terhadap Kinerja Guru.

Kriteria Uji : Tolak $\mathrm{H}_{\mathrm{o}}$ jika Sig. $\left\langle\alpha\right.$ atau $\mathrm{t}_{\text {hitung }}>\mathrm{f}_{\text {tabel }}$ Untuk pengaruh Kepemimpinan Kepala Sekolah, Motivasi dan Budaya Organisasi secara simultan terhadap Kinerja Gurudengan tingkat signifikan $(\alpha)=5 \%$, degree of freedom $(\mathrm{df})=(\mathrm{n}-2)=170-2=168$, diperoleh $\mathrm{f}_{\text {tabel }}=2.42$. Sedangkan $\mathrm{f}_{\text {hitung }}$ dapat dilihat pada tabel di bawah ini : 
Tabel

Hasil Perhitungan Nilai F

ANOVA $^{\text {a }}$

\begin{tabular}{|ll|r|r|r|r|r|}
\hline \multicolumn{2}{|l|}{ Model } & \multicolumn{1}{|c|}{$\begin{array}{l}\text { Sum of } \\
\text { Squares }\end{array}$} & df & Mean Square & F & \multicolumn{1}{c|}{ Sig. } \\
\hline 1 & Regression & 7084.385 & 3 & 2361.462 & 144.295 & $.000^{\mathrm{b}}$ \\
& Residual & 2716.676 & 166 & 16.366 & & \\
& Total & 9801.061 & 169 & & & \\
\hline
\end{tabular}

a. Dependent Variable: KINERJA

b. Predictors: (Constant), KOMPENSASI, KEPEMIMPINAN, MOTIVASI

Sumber : Hasil Pengolahan Data, 2017

Berdasarkan tabel di atas, menunjukan bahwa $f_{\text {hitung }}=144.295$ dan sig. 0,000. Pengaruh Kepemimpinan Kepala Sekolah $\left(\mathrm{X}_{1}\right)$, Motivasi $\left(\mathrm{X}_{2}\right)$ dan Budaya Organisasi $\left(\mathrm{X}_{3}\right)$ secara simultan terhadap Kinerja Guru(Y) diperlihatkan pada tabel di bawah ini :

Tabel

Pengaruh Simultan Kepemimpinan $\left(\mathbf{X}_{1}\right)$, Motivasi Kerja $\left(\mathbf{X}_{2}\right)$

Dan Budaya Organisasi $\left(\mathbf{X}_{3}\right)$ terhadap Kinerja Guru(Y)

\begin{tabular}{|c|c|c|c|c|c|}
\hline Structural & Sig. & $\boldsymbol{\alpha}$ & f hitung & $\mathbf{f}_{\text {tabel }}$ & Kesimpulan \\
\hline $\mathrm{Pyx}_{1}, \mathrm{x}_{2, \mathrm{X} 3}$ & 0,000 & 0,05 & 144.295 & 2.42 & $\mathrm{H}_{\mathrm{o}}$ ditolak \\
\hline
\end{tabular}

Sumber : Hasil Pengolahan Data, 2017

Tabel diatas menunjukan bahwa nilai sig. $(0,000)<\alpha(0,05)$ dan $f_{\text {hitung }}(144.295)>f_{\text {tabel }}$ (2.42) maka $H_{o}$ ditolak. Dengan demikian dapat disimpulkan bahwa Kepemimpinan Kepala Sekolah, Motivasi dan Budaya Organisasisecara simultan berpengaruh positif dan signifikan terhadap Kinerja Guru.

\section{F. SIMPULAN}

Berdasarkan hasil penelitian, pengumpulan data dan pembahasan yang dilakukan peneliti pada SMA dan SMK se Kecamatan Jatiasari Karawang maka dapat di ambil kesimpulan sebagai berikut :

1. Kinerja Guru pada SMA dan SMK se Kecamatan Jatiasari Karawang sudah baik, karena indikator yang diteliti dengan total skor sebesar 8.927 dan nilai rata-rata yaitu 637.6 yang berada pada rentang skala 578,3714,4 berada pada kriteria setuju.

2. Kepemimpinan Kepala Sekolah pada SMA dan SMK se Kecamatan Jatiasari Karawang sudah baik, karena Indikator yang diteliti dengan total skor sebesar 8.299 dan nilai rata-rata yaitu 592.8, yang pada rentang skala 578,3-714,4berada pada kriteria setuju.

3. Motivasipada SMA dan SMK se Kecamatan Jatiasari Karawang yang diberikan kepada Guru sudah baik, karena indikator yang diteliti dengan total skor sebesar 8.643 dan nilai rata-rata yaitu 617.3 yang berada pada rentang skala 578,3-714,4. 
4. Budaya Organisasi pada SMA dan SMK se Kecamatan Jatiasari Karawangsudah baikkarena indikator yang diteliti dinyatakan setuju oleh responden dengan total skor 8.585 dengan rata-rata 613.2, yang berada pada rentang skala 578,3-714,4.

5. Terdapat pengaruh parsial antara Kepemimpinan Kepala Sekolah terhadap Kinerja Guru sebesar 14.6\%. hal ini mendukung penelitian Yulia Racmawati (2013), Titik Handayani dan Aliyah A. Rasyid (2015), Satrijo Budiwibowo (2014). Terdapat pengaruh parsial antara Motivasiterhadap Kinerja Guru sebesar 24.8\%. Hal ini mendukung penelitian Endy Eros (2014), Iskandar (2012), I Ketut Darmada, Nyoman Dantes dan Nyoman Natajaya, Hari susanto (2012) dan nur cahya edy sukendar (2013). Terdapat pengaruh parsial Budaya Organisasi Terhadap Kinerja Guru sebesar $32.9 \%$. Hal ini mendukung penelitian yang telah dilakukan olehTitik Handayani dan Aliyah A. Rasyid (2015), Mishan (2015),dan Lina Sugiyanto (2014).

6. Kepemimpinan Kepala Sekolah, Motivasi dan Budaya Organisasisecara simultan berpengaruh positif dan signifikan terhadap Kinerja Guru. Total pengaruh yang disebabkan Kepemimpinan Kepala Sekolah, Motivasi dan Budaya Organisasi terhadap Kinerja Guru yaitu sebesar $72.3 \%$ adapun pengaruh variabel lain diluar model adalah sebesar $27.7 \%$. Hal ini mendukung penelitian Titik Handayani dan Aliyah A. Rasyid (2015).

\section{G. SARAN}

Berdasarkan dari hasil penelitian yang dilakukan dan dalam kesempatan ini penulis akan sedikit memberikan beberapa saran, diharapkan dapat menjadi bahan masukan dan bahan pertimbangan bagi SMA dan SMK se Kecamatan Jatiasari Karawang yang sifatnya untuk kemajuan perusahaan tersebut:

1. Diharapkan Sekolah terus meningkatkan karya inovatif Guru dengan cara menumbuhkan rasa percaya diri kepada para guru untuk berani menciptakan hal-hal yang baru.

2. Diharapkan Kepala Sekolah meningkatkan kepemimpinannya terutama untuk menjadi seorang motivator yang efektif dengan cara selalu siap sedia dimanapu dan kapanpun jika guru membutuhkan bantuan serta mudah untuk dihubungi.

3. Diharapkan Sekolah dapat terus meningkatkan semangat kerja Guru agar dapat bekerja secara optimal dengan cara memberikan reward untuk guru yang terbaik dan memberikan sanksi bagi guru yang kurang baik.

4. Diharapkan Sekolah dapat meningkatkan kecermatan guru dalam menjalankan tugas sebagai pengajar.

5. Diharapkan sekolah terus mempertahankan presentasi yang sudah besar serta meningkatkan yang masih kurang pada variable kepemimpinan kepala sekolah, motivasi, budaya organisasi dan Kinerja guru. Agar sekolah dapat meningkatkan kualitas pendidikan dan mencetak lulusan terbaik yang mampu bersaing dengan sekolah lain yang sederajat.

Diharapkan untuk penelitian selanjutnya dapat ditambahkan variable lain seperti kompensasi dan kompetensi sehingga dapat lebih diketahui pengaruhnya terhadap kinerja guru. 
H. DAFTAR PUSTAKA

I. Buku Dan Jurnal

Bangun, Wilson.2012.Manajemen Sumber Daya Manusia. Jakarta: Erlangga

Buku Pedoman Penyusunan Tugas Akhir Mahasiswa S2 Manajemen. 2017. Fakultas Ekonomi Universitas Singaperbangsa Karawang

Endy Eros.2014. Pengaruh Motivasi Dan Kedisiplinan Kerja Guru

Terhadap Kinerja

Guru Di SMP Negeri Kecamatan Brebes Kabupaten Brebes Jawa

Tengah. Jurnal Administrasi Publik dan Birokrasi Vol. 1 No. 1,

2014, Universitas Terbuka (Diakses tanggal 1 Mei 2017, 04.04)

Fahmi, Irham, 2011. Manajemen Kinerja. Edisi ke Satu, Penerbit Alfabeta, Bandung.

Hamzah B Uno. 2014. Teori motivasi dan pengukurannya dibidang pendidikan. Jakarta: Bumi aksara

Handoko, T Hani. 2008. Manajemen. Edisi 2. BPFE, Yogyakarta.

2012. Manajemen. BPFE, Yogyakarta.

H. Muhammad Arifin. 2015. The Influence of Competence, Motivation, and Organisational Culture to High School Teacher Job Satisfaction and Performance. International Education Studies; Vol. 8, No. 1; 2015 ISSN 1913-9020 E-ISSN 1913-9039, School of Communication, Muhammadiyah Jayapura (Diakses tangal 5Mei 2017, 09:16)

Hasibuan, Malayu. S. P. 2011 Manajemen dasar Pengertian dan Masalah Edisi

Revisi .Jakarta: Bumi Aksara

Indrawijaya, Adam Ibrahim. 2010. Teori Perilaku dan Budaya Organisasi. Bandung:

Refika Aditama

I Ketut Darmada, Nyoman Dantes dan Nyoman Natajaya. 2009. Kontribusi Kompetensi Manajerial Kepala Sekolah, Iklim Kerja Dan Motivasi Kerja Terhadap Kinerja Guru SMP Negeri Se Kecamatan Mendoyo Kabupaten Jembrana.Journal Program Pascasarjana Universitas Pendidikan Ganesha Jurusan Pendidikan Dasar (Volume 3 Tahun 2013). (Diakses Tanggal 3 Mei 2017. 08:01)

Iskandar, 2012. Pengaruh Motivasi Dan Lingkungan Kerja Terhadap Kinerja Guru

83. 
Sma Negeri Se-Kabupaten Kendal.Jurnal Educational Management 1, ISSN 2252-7001, Universitas Negeri Semarang (Diakses Tanggal 04 Mei 2017, 10:53).

Lina Sugiyanto, 2014. Analisis Pengaruh Budaya Organisasi Dan Motivasi Terhadap Kinerja Dosen Pada Universitas Soerjo Ngawi. MEDIA SOERJO Vol. 14 No 1 April 2014 ISSN 1978 - 6239Universitas Soerjo Ngawi. (Diakses tanggal 4 Mei 2017, 02:55)

Mangkunegara, A.A Anwar Prabu. 2008. Manajemen Sumber Daya Manusia

Perusahaan. Bandung: Remaja Rosda karya.

Manullang. 2012. Dasar-Dasar Manajemen. Yogyakarta: UGM Gajah Mada

University Press

Mishan, 2014. Pengaruh Motivasi Kerja Guru Dan Budaya Organisasi Terhadap

Kinerja Guru SMA Negeri Di Kota Sibolga. Jurnal Bisnis dan Manajemen Eksekutif Vol. 1 No. 2, Universitas Terbuka. (Diakses Tanggal 6 Mei

2017, 12:59)

Mulyasa. 2011. Manajemen Berbasis Sekolah Konsep Strategi Dan Implementasi.

Bandung: Remaja Rosdakarya.

Nur Cahya Edi Sukendar.2013. Pengaruh Keterampilan Kepemimpinan Kepala

Sekolah Dan Motivasi Kerja Guru Terhadap Kinerja Guru Smp Negeri Di Sub Rayon 03 Kabupaten Jepara. Jurnal JMP, Volume 2 Nomor 1, April 2013, IKIP PGRI Semarang. (Diakses 4 Mei 2017. 01.03)

Pabundu, Tika. 2010. budaya organsasi dan peningkatan kinerja perusahaan. Cetakan ketiga. Jakarta: Bumi Aksara

Rachmawati, Yulia. 2013. Pengaruh Kepemimpinan Kepala Sekolah Terhadap

Kinerja Guru. Jurnal Pendidikan Ekonomi Vol. 01 No. 01, Juni 2013, IKIP Veteran Semarang. (Diakses Tanggal 3 Mei 2017, 04.20)

Rivai,Veithzal. 2011. Manajemen Sumber Daya Manusia untuk Perusahaan.

Jakarta: Rineka Cipta. 2012. Manajemen Sumber Daya Manusia untuk Perusahaan. 
Jakarta: Rineka Cipta.

Satrijo Budiwibowo. 2014. Pengaruh Gaya Kepemimpinan Transaksional, Transformasional Dan Disiplin Kerja Terhadap Kinerja Guru (Karyawan) Di Kota Madiun. Premiere Educandum, Volume 4 Nomor 2, Desember 2014, IKIP PGRI Madiun. (Diakses Tanggal 1 Mei 2017. 00.02)

Sembiring, Masana. 2012. Budayadan Kinerja Organisasi. Focus media: Bandunng

Siswanto, HB. 2010. Pengantar Manajemen. Jakarta: Bumi Aksara

Silalahi, Uber. 2012. Metode Penelitian Sosial. Bandung: Refika Aditama

Sopiah. 2008. Perilaku Organisasi. Edisi kesatu. Yogyakarta : Andi

Sugiyono, 2012. Metode Penelitian Kuantitatif, Kualitatif, dan $R \& D$. Penerbit

Alfabeta, Bandung.

Supardi. 2014. Kinerja Guru. Jakarta: Raja Grafindo.

Sutrisno, Edy. 2009. Manajemen Sumber Daya Manusia. Jakarta: Kencana.

Suwatno \& Donni Juni Priansa. 2011. Manajemen SDM Dalam Organisasi Publik

dan Bisnis, Alfabeta, Bandung.

Titik Handayani dan Aliyah A. Rasyid. 2009. Pengaruh Kepemimpinan Kepala

Sekolah, Motivasi Guru, Dan Budaya Organisasi Terhadap Kinerja Guru Sma Negeri Wonosobo. Jurnal Akuntabilitas Manajemen Pendidikan, Volume 3, No 2, September 2015, Universitas Negeri Yogyakarta (Diakses Tanggal 6 Mei 2017, 04.12)

Umam, Khaerul. 2010. Perilaku Organisasi. Bandung: Pustaka Setia

Usman, Husaini. 2011. Manajemen Teori Praktik dan Riset Pendidikan. Jakarta:Bumi Aksara

Wiludjeng, Sri. 2007. Pengantar Manajemen. Yogyakarta: Graha Ilmu

Yani, AsepTapip. 2011. Manajemen Sumber Daya Manusia. Bandung. Humaniora

\section{Peraturan, Kebijakan dan Buku Pedoman}

1. Peraturan Pemerintah No. 46 Tahun 2011 
2. Peraturan Menteri Pendayagunaan Aparatur Negara dan Reformasi Birokrasi No 16 tahun 2009 